\title{
The acute toxicity assesment of Mospilan RP and Actara 25 WG for White Mice
}

\author{
Volodymyr Dukhnytskyi ${ }^{1}$, Vasily Sokolyuk ${ }^{2 *}$, Petro Boiko ${ }^{3}$, Irina Ligomina ${ }^{2}$ and Vladimir Goncharenko ${ }^{1}$ \\ ${ }^{I}$ National University of Life and Environmental Sciences of Ukraine, Heroyiv Oborony st., 15, Kyiv - 03041, Ukraine \\ ${ }^{2}$ Zhytomyr National Agroecological University, Zhytomyr, Staryi Blvd., 7, Zhytomyr, 10008, Ukraine \\ ${ }^{3}$ Lesya Ukrainka Eastern European National University, Volya Avenue, 13, Lutsk, 43025, Ukraine \\ *Corresponding author's Email: vmsokoluk@gmail.com; ORCID: 0000-0003-2311-1910
}

Received: 01 Apr. 2020

Accepted: 15 May 2020

\begin{abstract}
In this article an attempt was made to present the results of toxicity assessment of insecticides from the group of neonicotinoids, Mospilan RP (active substance acetamiprid) and Actara 25 WG (active substance thiamethoxam) in white mice. The aim was to investigate the acute toxicity of Mospilan RP and Actara 25 WG in white mice. The halflethal dose (LD50) of Mospilan RP was found to be131.25 $\pm 34.12 \mathrm{mg} / \mathrm{kg}$ Body Weight (BW) per active substance and $656.25 \pm 170.6 \mathrm{mg} / \mathrm{kg} \mathrm{BW}$ per drug, and the Lethal Dose (LD100) was $200 \mathrm{mg} / \mathrm{kg} \mathrm{BW}$ by the active ingredient (1000 mg/kg BW by drug). The half-life dose (DL50) of Actara $25 \mathrm{WG}$ for white mice was $907.81 \pm 24.03 \mathrm{mg} / \mathrm{kg}$ BW for the active substance, and $3631.24 \pm 96.12 \mathrm{mg} / \mathrm{kg} \mathrm{BW}$ for the drug; The lethal dose (LD100) was also 1200 $\mathrm{mg} / \mathrm{kg} \mathrm{BW}$ per active ingredient (4800 mg/kg BW per drug). The acute course of poisoning by Mospilan RP and Actara $25 \mathrm{WG}$ in mice was characterized mainly by nervous disorders (lesions of the central and peripheral nervous systems), which is evidenced by the clinical features of poisoning including depression, convulsions, ataxia (impaired movement coordination), tremor and impaired breathing. It has been established that Mospilan RP belongs to the third toxicity class according to the Hygienic classification of substances by skin-resorptive toxicity (DL50>2000 $\mathrm{mg} / \mathrm{kg})$.
\end{abstract}

Key words: Actara 25 WG insecticides, Acute toxicity, Insecticides toxicity, Mospilan PP, Neonicotinoids, White mice

\section{INTRODUCTION}

In Ukraine, Imidacloprid (included in the drug Confidor, $20 \%$ bp), Thiacloprid (Calypso drug, 48\% bp), Acetamiprid (Mospilan drug, 20\% pp), Thiamethoxam (Actor $25 \mathrm{WG}$ preparation for the cultivation of vegetative crops), and neo-nicotinic insecticides are used as seed dressing agents for protecting of orchards (apple, plum), vineyards and field crops (corn, potatoes, tomatoes, cucumbers, hops, sugar beets, cereals, rapeseed, sunflower) (Bazaka et al., 2018).

In recent years, there has been an increasing amount of using anti-ectopatasite agents for dogs and cats in the veterinary practice which are based on two active substances; neonicotinoids -Nitenpyram (tablets Capstar, by Novartis Switzerland) and Imidacloprid, manufactured by the German company, Bayer Krop Sayens AG. The agents containing active substances, Imidacloprid or Thiamethoxam have been registered for home usage, public health or veterinary practice for the purposes of disinfestation. Granular baits such as Kvik Byte VG 10 (10\% imidacloprid, Kvizda Agro GmbH, Austria), Agita (10\% thiamethoxam, Novartis, Switzerland), and Adamant bait for flies (1\% thiamethoxam, Russia) are allowed to be used for fly control in the livestocks (Smith et al., 2016).

It is believed that Neonicotinoids act selectively on the target sites, and its toxicity to animals and humans is not much significant (Ford and Casida, 2008). According to the chemical structures, Neonicotinoids are charecterized to the class of nitromethylene heterocyclic compounds. They are suggested to be highly efficient at low cost rates, and relatively harmless to non-target organisms and the environment (Abrieux et al., 2016). Despite its safty and efficacy, there is evidence of Neonicotinoid toxicity to bees and other pollinator insects.consenquently, there are some restrictions imposed on the use of Imidacloprid, Thiamethoxam and Clothianidin in several European countries. What is not yet clear is the untraceable side effects of Neonicotinoids 
on the animals' body, due to their vast usage in the agriculture. Previous studies in Japan have demonstrated a high sensitivity of rats' brain receptors to the effects of Imidacloprid and Acetamiprid in low doses (KimuraKuroda et al., 2012).

In addition, a group of Turkish scientists have found the effects of Imidacloprid at doses $(0.5 ; 2$ and $8 \mathrm{mg} / \mathrm{kg}$ Body Weight (BW) for three months) on the reproduction system of male rats, indicating impaired mobility and morphological structure of sperms, as well as a significant decrease in the level of blood testosterone, activation of germ cell apoptosis, DNA fragmentation, and changes in the composition of fatty acids (Bal et al., 2012a).

Clotianidin at a dose of $32 \mathrm{mg} / \mathrm{kg} / \mathrm{day}$ has been also found to have negative effects on the reproductive functions of male rats, as a result of a significant decrease in the absolute weight of the right testicle appendage and the seminal vesicles, a decrease in the concentration of sperms, testosterone and glutathione, as well as a decrease in the number of abnormal germ cell forms, and DNA fragmentation (Bal et al., 2012b). However, the same authors indicated that Clothianidin has a slight effect on the reproductive capacity of male rats in later publications (Bal et al., 2013).

Imidacloprid and Thiacloprid have been discussed to have embryotoxic effects. While the authors do not describe the type of changes in the reproductive organs of males and females, it is only mentioned that pesticides provoke abortions in the pregnant females (Basaka et al., 2018). Neonicotinoids are not believed to be absorbed by the skin due to their poor solubility in lipids, so acute toxicity is more evident when they are taken orally. Inacute cases of toxicity, neonicotinoids are considered mild and hazardous compounds. The prolonged exposure of the active substances in this group to laboratory animals is characterized by a general effect on the body with a predominant hepatotoxic effect (Felsot, 2001).

Acute oral toxicity of Acetamiprid (DL50) (active ingredient in the commercial drug Mopilan) for rats is 146-217 mg/kg BW, and for mice is $184-198 \mathrm{mg} / \mathrm{kg} \mathrm{BW}$. Acute dermal toxicity of $>2000 \mathrm{mg} / \mathrm{kg} \mathrm{BW}$ to rats does not irritate rabbits' skin and their mucous membranes. Acute oral toxicity for quails is $180 \mathrm{mg} / \mathrm{kg} \mathrm{BW}$, and Lethal Concentration 50\% (CL50) (24-96 years)is more than 100 $\mathrm{mg} / \mathrm{l}$, CL50 (3-6 h) for craps, and more than $1000 \mathrm{mg} / \mathrm{l}$ for Daphnias (Basaka et al., 2018).

The clinical features of intoxication are characterized by decreased activity, salivation, tremor, convulsions, ataxia, lateral recumbency, and in severe cases, hemorrhages in the lungs may cause death.
Acetamiprid is low toxic on the skin of rats for 24 hours. No clinical signs of intoxication and no irritant effects were found in DL50 in males and females at the doses greater than $2000 \mathrm{mg} / \mathrm{kg}$ BW.additionally, no macroscopic changes have been observed in the internal organs (Basaka et al., 2018). Oral toxic dose of Thiamethoxam (DL50) (active ingredient of the commercial preparation of Actara) is $1563 \mathrm{mg} / \mathrm{kg} \mathrm{BW}$ in rats, and $871 \mathrm{mg} / \mathrm{kg} \mathrm{BW}$ in mice. Its acute dermal toxicity (DL50 24 hours) is more than $2000 \mathrm{mg} / \mathrm{kg}$ parts per million (ppm) in rats. However, recent studies about to determine the toxicity of Neonicotinoids to bees by A.I. Illarionov (Illarionov, 2012) indicates a relationship betweenthe death of bees and contacting to the plants treated with Thiamethoxam or Imidacloprid on the day of drugs use. Moreover, several studies have been made to show the potential danger of neonicotinoids for bees (Decourtye et al., 2003; Decourtye and Devillers, 2010).

Overall, these studies provide important insights into the toxicological characteristics of Neonicotinoids. They will allow to expand and supplement the information on the potential danger of Neonicotinoids and will promote their safe usage in theagriculture and veterinary medicine.

\section{MATHERIELS AND METHODS}

Experimental studies on white mice were prepared according to the procedure of Toxicological Control of New Animal Protection guidelines (Denisenko, 2013), existing documents organizing the work with laboratory animals, and the principles of the European Convention on the Protection of Vertebrate Animals for experimental and scientific purposes "(Strasbourg, 1986) and Art. 26 of the Law of Ukraine No. 5456-VI of 16.10.2012. "On the Protection of Animals from Cruelty". Afterward, 104 nonlinear white mice weighing 18-20 gram were examined for acute toxicity of Mospilan RP and Actara 25 WG.

Previous study based its criteria on the method established by G. Kerber to measure the half-life dose. The direct results of the study were used to calculate the LD50. The mice were divided into equivalent groups (at least 6 mice in each one). Regarding the doses, they included LD50 and LD100 taken in different intervals for 4-5 times which were believed to be sufficient. The study was conducted in the vivarium of the Veterinary Medicine Faculty of the National University of Life and Environmental Sciences of Ukraine. Before starting the study, the mice were kept for 7 days during the adaptation period, in which a daily close observation of their clinical 
condition was done. They have been hungry for 3-4 hours before the experiment started. The drug solutions were administered orally using a calculated probe, so that the solution volume did not exceed 0.4 mililiter $(\mathrm{ml})$. The dose was calculated in milligram (mg) of active substance (AS) per $1 \mathrm{~kg}$ body weight (BW).

Twelve groups (6 groups of mice to determine the acute toxicity of Mospilan RP and 6 groups of mice to determine the acute toxicity of Actara $25 \mathrm{WG}$ ), and one control group (in each group $n=8$ ) were set to conduct the studies on the determination of acute toxicity parameters.The mice of the experimental groups for Mospilan RP acute toxicity took 400; 200; 150; 100; 50 and $25 \mathrm{mg} / \mathrm{kg}$ body weight of the drug orally including the active substance.

the mice grouped for parameter determination of Actara 25 WG acute toxicity also took the drug orally at a rate of $1200.0 ; 1000.0 ; 875.0 ; 600.0 ; 437.5$ and 218.8 $\mathrm{mg} / \mathrm{kg} \mathrm{ppm}$ in terms of AS. Mice in the control group were administered distilled water in a volume of $0.4 \mathrm{ml}$.

During the study, the clinical condition of the animals were carefully monitored for 14 days. The animals were constantly monitored on the first day. Theappearance, reaction to stimuli, changes in body position, behavior, food and water intakes, the intensity and type of locomotor activity, the condition of the skin and mucous membranes were taken into account, and the development of intoxication and their death were recorded.

As a result of the studies in mice, lethal (DL100) and semi-lethal (DL50) doses of the studied drugs were used.

\section{RESULTS AND DISCUSSION}

One of the first and most important steps for determining the toxicological characteristics of a substance is to study its acute toxicity. Thepurpose of studying acute toxicity is to find out the toxic effects of the drug with a single injection, and to determine lethal, toxic and non-toxic doses. Acute toxicity studies include the recording of specific and nonspecific symptoms of intoxication, the general pattern of poisoning, its onset, course and consequences. The main parameter of acute toxicity is the DL50 (which leads to the death of 50\% of animals after single or multiple administration over a short period of time). The average lethal (semi-lethal) dose (DL50) of the toxic substance is determined in $\mathrm{mg} / \mathrm{kg} \mathrm{BW}$, and administered orally (or subcutaneously, intravenously, intraperitoneally, subcutaneously) in weeks.

The available literature indicated that Acetamiprid and Thiamethoxam are low-toxic substances. The half-life of Acetamiprid (DL50) is $213 \mathrm{mg} / \mathrm{kg}$ BW for white rats, and $98 \mathrm{mg} / \mathrm{kg}$ BW for poultry. The DL50 of Thiamethoxam is $1563 \mathrm{mg} / \mathrm{kg} \mathrm{BW}$ for white rats, and 576 $\mathrm{mg} / \mathrm{kg} \mathrm{BW}$ for poultry.

In order to find the lethal dose of Mospilan RP, the mice were separated to six experimental groups and a control one $(n=8)$. Themice in the experimental groups were orally administered an aqueous solution of $0.4 \mathrm{ml}$ of Mospilan RP at doses of 2000, 1000, 750, 500, 250, 125 $\mathrm{mg} / \mathrm{kg} \mathrm{BW}$ (which for DR was 400; 200; 150; 100; 50 and $25 \mathrm{mg} / \mathrm{kg} \mathrm{BW}$ ), and the control group took distilled water in a volume of $0.4 \mathrm{ml}$.

The response of the experimental groups to the drug was as same as the control one's, while the mice hada a reaction to the stress caused by manipulation, There was a slight increase in locomotor activity in the first few seconds, followed by sedation of the animals. Thirst was not noticed. Changes in the general condition of micewere found in 1-5 min in animals in groups 1,2 and 3 after they took the drug (Mospilan RP at the dose of 2000, 1000, 750 $\mathrm{mg} / \mathrm{kg} \mathrm{BW}$ ). the development of signs such as depression, rapid breathing, clonic-tonic convulsions, tremor, and bouncing were exactly observed. The mice moved individually in the cage, 5 to 8 minutes after drug administration.clinical signs of inhibition increased, and the animals were supine. The average time of death for animals in the 1st and 2nd experimental groups (all were killed) was 6.5 minutes. In the group 3, 5 out of 8 animals were killed within 5 hours. No further death was observed. Relating to the mice in the group 4, the signs described were less pronounced and longer, and 2 animals were killed within 12 hours. The animals in the experimental group 5 showed mild signs of impaired locomotor activity during the first 1.5 to 2 hours, which then disappeared. The condition of animals in the experimental group $6 \mathrm{did}$ not differ from the animals in the group 7 (control group).

The results of the determination of the acute toxicity of Mospilan RP are given in table 1. The data in the table show a strong evidence of Mospilan RP toxicity to white mice on oral administration at the doses of $100 \mathrm{mg} / \mathrm{kg}$ or more. From the data, it can be seen that the deaths of mice in the experimental groups range from two to eight mice.

$$
\mathrm{DL}_{50}=\mathrm{DL}_{100}-\frac{\sum z d}{m}
$$

$\mathrm{DL}_{100}$ : the dose of the substance investigated that caused the death of all animals in the group.

$d$ : the interval between two adjacent doses; $z:=$ arithmetic mean of animals killed by two adjacent doses; $m$ : the number of animals in each group.

The results of these calculations are shown in table 2 . 
Table 1. Protocol and the results of the acute experiment with oral administration of Mospilan RP to white mice in 2016, based on the Department of Pharmacology and Toxicology of the National University of Life and Environmental Sciences of Ukraine.

\begin{tabular}{|c|c|c|c|c|c|c|c|c|}
\hline \multirow{2}{*}{\multicolumn{2}{|c|}{ Dose, mg/kg }} & \multirow{3}{*}{$\begin{array}{l}\text { Number of } \\
\text { animals in a } \\
\text { group }\end{array}$} & \multicolumn{5}{|c|}{ The number of animals dead } & \multirow{3}{*}{$\begin{array}{c}\text { The average time of } \\
\text { death }(\mathrm{h})\end{array}$} \\
\hline & & & \multicolumn{3}{|c|}{ In days } & \multirow[b]{2}{*}{ all } & \multirow[b]{2}{*}{ in $\%$} & \\
\hline $\begin{array}{l}\text { By acceptable level } \\
\text { (active substance) }\end{array}$ & By the sa drug & & 1 & 2 & 15 & & & \\
\hline 400 & 2000 & 8 & 8 & - & - & 8 & 100 & 0.1 \\
\hline 200 & 1000 & 8 & 8 & - & - & 8 & 100 & 0.1 \\
\hline 150 & 750 & 8 & 5 & - & - & 5 & 62.5 & 3 \\
\hline 100 & 500 & 8 & 2 & - & - & 2 & 25 & 12 \\
\hline 50 & 250 & 8 & 0 & - & - & 0 & 0 & - \\
\hline 25 & 125 & 8 & 0 & - & - & 0 & 0 & - \\
\hline
\end{tabular}

This data is sufficient to calculate the DL50.

Table 2. Toxicity assessment of Mospilan RP according to G. Kerber method on white mice weighing 18-20 grams in 2016, based on the Department of Pharmacology and Toxicology of the National University of Life and Environmental Sciences of Ukraine.

\begin{tabular}{|c|c|c|c|c|c|}
\hline $\begin{array}{l}\text { Dose, } \mathrm{mg} / \mathrm{kg} \\
\text { (by active substance) }\end{array}$ & 25 & 50 & 100 & 150 & 200 \\
\hline Survived & 8 & 8 & 6 & 3 & 0 \\
\hline Dead & 0 & 0 & 2 & 5 & 8 \\
\hline $\mathrm{Z}$ & \multicolumn{2}{|c|}{0} & \multicolumn{2}{|c|}{3.5} & 6.5 \\
\hline $\mathrm{d}$ & \multicolumn{2}{|c|}{25} & \multicolumn{2}{|c|}{50} & 50 \\
\hline $\mathrm{Zd}$ & \multicolumn{2}{|c|}{0} & \multicolumn{2}{|c|}{175} & 325 \\
\hline$\Sigma z d$ & \multicolumn{5}{|c|}{550} \\
\hline
\end{tabular}

$\mathrm{d}:=$ the interval between two adjacent doses; $\mathrm{z}$ : arithmetic mean of animals killed by two adjacent doses

In the present study, $\mathrm{m}=8 ; \mathrm{DL}_{100}=200 \mathrm{mg} / \mathrm{kg}$ of body weigh by Acceptable Level (AL);

$\mathrm{DL}_{50}=200-(550 / 8)=200-68.75=131.25 \mathrm{mg} / \mathrm{kg}$ of BW by AL; DL84 and DL16 were calculated using the two-point method, which examined two doses of substances selected in such a way that the frequency of the alternative effect was less than $50 \%$ in one case and higher in the other. The equation of a line passing through two points was used:

$$
\frac{Y-Y_{1}}{Y_{2}-Y_{1}}=\frac{X-X_{1}}{X_{2}-X_{1}}
$$

$\mathrm{X} 1$ and $\mathrm{X} 2$ are the values of the two doses tested;

$\mathrm{Y} 1$ and $\mathrm{Y} 2$ are the respective mortality rates.

$\frac{84-25}{62.5-25}=\frac{X-100}{150-100}$, thus we get $\mathrm{X}=\mathrm{DL}_{84}=$

$178,67 \mathrm{mg} / \mathrm{kg}$ BW by active substance.

Similarly, DL16 is calculated.

$\frac{16-25}{62.5-25}=\frac{X-100}{150-100}$, thus we get $\mathrm{X}=\mathrm{DL}_{16}=88,0$ $\mathrm{mg} / \mathrm{kg}$ of boy weight by active substance .

The confidence limits of the DL50 are found by the method of K. Miller and M. Tainter by the formula DL50 $\pm \mathrm{mt}$. In this case, $2 \sigma=$ DL84 - DL16, and the mean error (m) of the half-lethal dose is

$$
m=\frac{2 \sigma}{\sqrt{N^{\prime} \times 2}},
$$

$\mathrm{N}$ 'is the total number of animals in groups in which at least one animal died or survived.

According to our data, $2 \sigma=90.7$;

$m=\frac{90,7}{\sqrt{16 \times 2}}=\frac{90,7}{5,66}=16,02$

The value of $\mathrm{t}$ is found from the Student's table, guided by a given value of $\mathrm{P}=0.05$, for the number of degrees of freedom $f=N^{\prime}-1$.

$\mathrm{t}=2.13$

Confidence limits $\mathrm{DL}_{50}$

$\mathrm{mt}=16.02 \times 2.13=34.12$

$\mathrm{DL}_{50} \pm \mathrm{mt}=131.25 \pm 34.12 \mathrm{mg} / \mathrm{kg}$ BW by active substance.

As a result of the experiment, it was found that the half-lethal dose of Mospilan RP insecticide preparation is DL50 $\pm \mathrm{mt}=131.25 \pm 34.12 \mathrm{mg} / \mathrm{kg} \mathrm{BW}$ for active substance $(656.25 \pm 170.6 \mathrm{mg} / \mathrm{kg}$ for the preparation).

Lethal dose, DL100 $=200 \mathrm{mg} / \mathrm{kg} \mathrm{ppm}$ for active substance $(1000 \mathrm{mg} / \mathrm{kg}$ for drug). Due to the certain acute toxicity indicators according to the toxicity classification of substances, the investigated insecticidal drug Mospilan RP belongs to class IV - low toxic (DL50 $=501-5000$ $\mathrm{mg} / \mathrm{kg} \mathrm{BW}$ ), according to the classification of chemicals in 
accordance with the degree of danger (GOST 12.1.007-76) it belongs up to the third class (DL50 $=151-5000 \mathrm{mg} / \mathrm{kg}$ BW).

Six experimental groups of mice and one control group $(n=8)$ were formed to determine the acute toxicity parameters of Actara $25 \mathrm{WG}$ preparation. The experimental drug was administered orally to the animals at a rate of $4800.0 \mathrm{mg} / \mathrm{kg} \mathrm{BW}$ in the first group, 4000.0 $\mathrm{mg} / \mathrm{kg} \mathrm{BW}$ in the second, $3500.0 \mathrm{mg} / \mathrm{kg} \mathrm{BW}$ in the third, $2400.0 \mathrm{mg} / \mathrm{kg} \mathrm{BW}$ in the fourth; $1750 \mathrm{mg} / \mathrm{kg} \mathrm{BW}$ in the fifth, and $875.2 \mathrm{mg} / \mathrm{kg} \mathrm{BW}$ in the sixth experimental group, which for DR was 1200.0, 1000.0, 875.0, 600.0, 437.5 and $218.8 \mathrm{mg} / \mathrm{kg} \mathrm{BW}$, respectively. For the control group, distilled water in a volume of $0.4 \mathrm{ml}$ was administered to the mice. The animals were monitored for 14 days, and their dynamics of changes in their clinical conditions were observed. On the first day, the animals were under constant surveillance.

According to the results of the experiment, a lethal (DL100) and a half-lethal (DL50) dose of the study drug was set up. The animals' response in the experimental groups to the drug introduction was as same as that of the animals of the control group when the placebo was taken, while the mice had a stressful reacrion to manipulation.. Although there was a slight arousal for the first few seconds, the mice settled down after a while. After the grug was administered, changing in their general conditions were observed for 5 to 10 minutes in the mice of groups 1 and 2 (at doses of $4800,4000 \mathrm{mg} / \mathrm{kg} \mathrm{BW}$ ). Frequent breathing, convulsions, and muscle tremors were noticed, and the micebounced and moved individually in the cage. Over time, in 10-20 minutes after the drug used, signs of depression increased and the mice took a supine position.

The average death time of the animals in group 1 (all killed) was 15 minutes. In group 2, 7 out of 8 mice were killed within an hour. In group 3, 2 out of 8 mice were killed in 2 hours. No further death was observed. In the group 4, the signs described were less pronounced and prolonged, and no death was observed. In the mice of group 5, there was a mild inhibition during the first 1.5-2 hours. There were no significant differences in the condition of the mice in group5 and group 7.

Table 3 indicates the toxic effects of Actaras $25 \mathrm{WG}$ when administered orally to white mice in doses of 875 $\mathrm{mg} / \mathrm{kg} \mathrm{BW}$ in DR. As a result, the deaths of mice in the experimental groups ranges from two to eight mice. This data is sufficient to enable the DL50 to be calculated.

The results of calculations of the half-life dose of Actara 25 WG in accordance with the results obtained from the experiment (Table 3) using the Kerber method are shown in table 4.

Table 3. A protocol of the results of the oral administration of Actara 25 WG to white mice in 2016, basis on the Department of Pharmacology and Toxicology of the National University of Life and Environmental Sciences of Ukraine.

\begin{tabular}{|c|c|c|c|c|c|c|c|c|}
\hline \multirow{2}{*}{\multicolumn{2}{|c|}{ Dose, mg/kg }} & \multirow{3}{*}{$\begin{array}{l}\text { Number of } \\
\text { animals in a } \\
\text { group }\end{array}$} & \multicolumn{5}{|c|}{ The number of animals dead } & \multirow{3}{*}{$\begin{array}{c}\text { The average term } \\
\text { of death }(h)\end{array}$} \\
\hline & & & \multicolumn{3}{|c|}{ In days } & \multirow[b]{2}{*}{ all } & \multirow[b]{2}{*}{ in \% } & \\
\hline By active substance & By the drug & & 1 & 2 & 15 & & & \\
\hline 1200 & 4800 & 8 & 8 & - & - & 8 & 100 & 0.25 \\
\hline 1000 & 4000 & 8 & 7 & - & - & 7 & 87.5 & 1 \\
\hline 875 & 3500 & 8 & 2 & - & - & 2 & 25 & 2 \\
\hline 600 & 2400 & 8 & 0 & - & - & 0 & 0 & - \\
\hline 437.5 & 1750 & 8 & 0 & - & - & 0 & 0 & - \\
\hline 218.8 & 875.2 & 8 & 0 & - & - & 0 & 0 & - \\
\hline
\end{tabular}

This data is sufficient to calculate the DL50.

Table 4. Toxicity determination of Actara 25 WG by G. Kerber method

\begin{tabular}{|c|c|c|c|c|}
\hline $\begin{array}{l}\text { Dose, } \mathbf{~ m g} / \mathbf{k g} \\
\text { (by AL) }\end{array}$ & 600 & 875 & 1000 & 1200 \\
\hline Survived & 8 & 6 & 1 & 0 \\
\hline Dead & 0 & 2 & 7 & 8 \\
\hline Z & \multicolumn{3}{|c|}{4.5} & 7.5 \\
\hline $\mathrm{d}$ & \multicolumn{2}{|c|}{275} & \multicolumn{2}{|c|}{200} \\
\hline $\mathrm{Zd}$ & \multicolumn{4}{|c|}{2755621500} \\
\hline$\Sigma z d$ & \multicolumn{4}{|c|}{2337.5} \\
\hline
\end{tabular}


$\mathrm{m}=8 ; \mathrm{DL}_{100}=1200 \mathrm{mg} / \mathrm{kg} \mathrm{BW}$ by active substance;

$\mathrm{DL}_{50}=1200-(2337,5 / 8)=1200-292.19=907.81$ мГ/Кг мТ.

The average error $(\mathrm{m})$ of the half-lethal dose is equal:

$$
m=\frac{2 \sigma}{\sqrt{N^{\prime} \times 2}},
$$

$\mathrm{N}^{\prime}$ is the total number of animals in the groups in which at least one animal has died or survived.

In the present case (by the method of K. Miller and M. Tainter) $2 \sigma=\mathrm{DL}_{84}-\mathrm{DL}_{16}$. The indicators DL84 and DL16 are calculated using the two-point method, in which substances were studied in two doses selected in such a way that the frequency of the alternative effect was less than 50\% in one case and greater in the other. the equation of a line passing through two points is used:

$$
\frac{Y-Y_{1}}{Y_{2}-Y_{1}}=\frac{X-X_{1}}{X_{2}-X_{1}}
$$

$\mathrm{X} 1$ and $\mathrm{X} 2$ are the values of the two doses tested;

$\mathrm{Y} 1$ and $\mathrm{Y} 2$ are the respective mortality rates.

After calculations on the respective parameters of the mice in the experimental groups 2 and 3, it was found that DL84 $=993 \mathrm{mg} / \mathrm{kg}$ for active substance, and DL16 = $857.0 \mathrm{mg} / \mathrm{kg}$ of metric tons for AS. So if $2 \sigma=993-857=$ 136, then: $m=\frac{136}{\sqrt{16 \times 2}}=\frac{136}{5.66}=24.03$

$$
\mathrm{DL}_{50}=907.81 \pm 24.03 \mathrm{mg} / \mathrm{kg} \mathrm{BW} \text { by active }
$$
substance.

$\mathrm{DL}_{50}=3631.24 \pm 96.12 \mathrm{mg} / \mathrm{kg}$ of BW.

The half-lethal dose of the Actara 25 WG insecticide drug for white mice was $\mathrm{DL}_{50} \pm \mathrm{mt}=907.81 \pm 24.03 \mathrm{mg} / \mathrm{kg}$ BW (3631.24 $\pm 96.12 \mathrm{mg} / \mathrm{kg} \mathrm{BW})$; lethal dose $\mathrm{DL}_{100}=$ $1200 \mathrm{mg} / \mathrm{kg} \mathrm{BW}$ for active substance and $4800 \mathrm{mg} / \mathrm{kg} \mathrm{BW}$ for drug.

On the basis of certain indicators of acute toxicity according to the classification of toxic substances, the investigated insecticidal drug Aktara $25 \mathrm{WG}$ belongs to the class IV - low toxic (DL50 $=501-5000 \mathrm{mg} / \mathrm{kg} \mathrm{m}$.); according to the classification of chemicals about the degree of its danger (GOST 12.1.007-76), it belongs to up to the third class $\left(\mathrm{DL}_{50}=151-5000 \mathrm{mg} / \mathrm{kg} \mathrm{BW}\right)$.

According to the toxicity classification of substances, the results of half-lethal dose determination of Mospilan RP and Actara 25 WG when they are administered orally once to white mice indicate that the investigated insecticides are low-toxic. The DL50 values of the investigated preparations for white mice were $656.25 \pm 170.6 \mathrm{mg} / \mathrm{kg}$ BW for Mospilan RP (131.25 \pm $34.12 \mathrm{mg} / \mathrm{kg} \mathrm{BW}$ for DR), and $3631.24 \pm 96.12 \mathrm{mg} / \mathrm{kg}$
BW for Actara $25 \mathrm{WG}(907.81 \pm 24.03 \mathrm{mg} / \mathrm{kg} \mathrm{BW}$ for DR), which was somewhat dissimilar from the DL50 of active substances for white mice determined by another author (Tomlin, 2009).

The physicochemical properties of the auxiliaries and formants included in the preparations could be the reason of differences in the results.

The acute course of poisoning by Mospilan RP and Actara $25 \mathrm{WG}$ in mice was characterized mainly by nervous disorders (lesions of the central and peripheral nervous systems), as evidenced by the clinical features of poisoning, including depression, convulsions, ataxia (impaired movement coordination), tremor and impaired breathing. Ataxia could be a consequence of impulse transmission inhibition in the neuromuscular synapses (curative action), and interneuronal impulse transmission in the central nervous system. It is found that, at high concentrations of Acetylcholine in the blood and the effector organs, the inhibitory reaction developing as a result of the mediator's action at the central synapses is determined by the nervous system. Then, the inhibition extends to every part of the central nervous system, which is evidenced by the disorder of movement coordination in animals. The onset of tremor, and also convulsive syndrome in more sever cases result from central nervous system over-excitation. The leading role in this case was the developement of tissue hypoxia to which brain cells are most sensitive (Lavryshyn et al., 2016).

Respiratory disorders associated with the development of toxic encephalopathy and disorders of the regulatory function of the central nervous system are a pathogenetic basis for the development of hypoxia, which leads to a dysfunction of all vital organs and systems (Livanov, 2008).

Considering the mechanism of action of Neonicotinoids on insects, specifically their interaction with H-cholinoreceptors (Matsuda et al., 2001; Jones and Sattelle, 2010), it was assumed that the consequence of the excessive intake of nicotinic receptor agonists in animals was a violation of the efferent impulse transmissions in vegetative ganglia, cerebral ganglia, cerebral ganglion of synapses, in chemoreceptors and generation of afferent impulses in the carotid glomerulus, as well as in the interneuron transmission of excitation in the central nervous system. In this case, there was a two-phase effect on H-cholinoreceptors. the excitation stage was changed by the inhibition effect.

Overally, the pattern of acute toxicity of Mospilan RP and Actaraa 25 WG in this study was shown to have the 
same results as the other reaserch (Mohamed et al., 2009; See et al., 2009; Kammon et al., 2010; Iyadurai et al., 2010; Mossa et al., 2018).

\section{CONCLUSION}

According to the classification of substances by toxicity, the studied drugs Mospilan RP and Actara 25 WG are found to be in class IV - low toxic. Furthermore, according to the classification of chemicals in accordance with the degree of danger, they belong to up to class III, because the half-lethal dose of Mospilan RP for white mice was $\mathrm{DL}_{50} \pm \mathrm{mt}=656.25 \pm 170.6 \mathrm{mg} / \mathrm{kg} \mathrm{BW}$, and for Actors $25 \mathrm{WG}$ was $\mathrm{DL}_{50} \pm \mathrm{mt}=3631.24 \pm 96.12 \mathrm{mg} / \mathrm{kg}$ BW. It has been established that Mospilan RP belongs to the third toxicity class according to the Hygienic classification of substances by skin-resorptive toxicity (DL50 > $2000 \mathrm{mg} / \mathrm{kg}$ ).

\section{DECLARATIONS}

\section{Author's contribution}

Volodymyr Dukhnytskyi conducted the research, collected data and performed the statistical analysis. Vasily Sokolyuk, Petro Boiko, Irina Ligomina and Vladimir Goncharenko wrote the manuscript. All authors have read and approved the final manuscript.

\section{Competing interests}

The authors have declared that no competing interest exists.

\section{REFERENCES}

Abrieux A, Mhamdi A, Rabhi KK, Egon J, Debernard S, Duportets L, Tricoire-Leignel H, Anton S and Gadenne C (2016). An Insecticide Further Enhances Experience-Dependent Increased Behavioural Responses to Sex Pheromone in a Pest Insect. PLoS ONE, 11 (11): e0167469. DOI: https://doi.org/10.1371/journal.pone.0167469

Bal R, Türk G et al. (2012a). Assessment of imidacloprid toxicity on reproductive organ system of adult male rats. Journal of Environmental Science and Health, 47(5): 434-444. DOI: https://doi.org/10.1080/03601234.2012.663311.

Bal R,, Türk G, , Tuzcu M, , Yılmaz Ö,, Kuloğlu T, , Baydaş G, , Naziroğlu M, , Yener Z, , Etem E and and Tuzcu Z. (2013). Effects of the neonicotinoid insecticide, clothianidin, on the reproductive organ system in adult male rats. Drug and Chemical Toxicology, 36(4): 421-429. DOI: https://doi.org/10.3109/01480545.2013.776575.

Bal R, Türk G, Yılmaz Ö, Etem E, Kuloğlu T, Baydaş G and Naziroğlu M. (2012b). Effects of clothianidin exposure on sperm quality, testicular apoptosis and fatty acid composition in developing male rats. Cell Biology and Toxicology, 28(3): 187-200. DOI: https://doi.org/10.1007/s10565-012-9215-0.

Basaka G, Borysevich B and Dukhnitskiy V (2018). Pathoanatomical changes in the laying hens' organism at mospilan rp and aktara 25 wg chronic poisoning. Ukrainian journal of veterinary sciences, $285 . \quad$ Available at: http://journals.nubip.edu.ua/index.php/Veterenarna/article/view/124 $\underline{97}$

Bazaka GY, Dukhnitskyi VB and Ishchenko VD (2018). Comparative study of mospilana and akhtar chronic toxicity for white mice. Ukrainian journal of veterinary sciences, 265. Available at: http://journals.nubip.edu.ua/index.php/Veterenarna/article/view/106 $\underline{06}$

Decourtye Decourtye A and Devillers J (2010). Ecotoxicity of neonicotinoid insecticides to bees. Insect nicotinic acetylcholine receptors. New York: Springer, 683: 85-95. DOI: https://doi.org/10.1007/978-1-4419-6445-8 8 or available at:

Decourtye A, Lacassie E and Pham-Delégue M (2003). Learning performances of honeybees (Apis mellifera L.) are differentially affected by imidacloprid according to the season. Pest Management Science, 59 (3): 269-278. DOI: https://doi.org/10.1002/ps.631.

Denisenko SV (2013). Bioethical attitude to laboratory animals in the educational process. Bulletin of the Ukrainian Medical Dental Academy, 13, 2 (42): 242-245. Available at: https://cyberleninka.ru/article/n/bioetichne-stavlennya-dolaboratornih-tvarin-u-navchalnomu-protsesi

Felsot A (2001). Admiring risk reduction. Does imidacloprid haver what it takes? Agrichemical \& Environmental News, 186: 1-3. Available at: $\quad$ https://www.semanticscholar.org/paper/Admiring-RiskReduction-Does-Imidacloprid-Have-WhatFelsot/b1574ff1a8745f9ce55b46029a173c42a5c34a78

Ford KA and Casida JE (2008). Comparative metabolism and pharmacokinetics of seven neonicotinoid insecticides in spinach. Journal of Agricultural and Food Chemistry, 56(21): 10168-10175. DOI: https://doi.org/10.1021/jf8020909.

Illarionov AI (2012). Degree of danger of neonicotinoids for a honey bee. Agrochemistry, 3: 85-94. DOI or Available at: http://naukarus.com/stepen-opasnosti-neonikotinoidov-dlyamedonosnoy-pchely

Iyadurai RIA, George IA and Peter GJV (2010). Imidacloprid poisoningnewer insecticide and fatal toxicity. Journal of Medical Toxicology, 6: 77-78. DOI: https://doi.org/10.1007/s13181-010-0041-6.

Jones AK and Sattelle DB (2010). Diversity of insect nicotinic acetylcholine receptor subunits. Advances in Experimental Medicine and Biology, 683: 25-43. DOI: https://doi.org/10.1007/978-1-4419-6445-8 3.

Kammon AM, Rajinder SBand Banga HS (2010). Patho-biochemical studies on hepatotoxicity and nephrotoxicity on exposure to chlorpyrifos and imidacloprid in layer chickens. Veterinarski arhiv, 5 (80): 663-672. Available at: https://hrcak.srce.hr/62160.

Kimura-Kuroda J, Komuta Y, Kuroda Y, Hayashi M and Kawano H (2012). Nicotine-likeefects of the neonicotinoid insecticides acetamiprid and imidacloprid on cerebellar neurons from neonatal $\begin{array}{lllll}\text { rats. PLoS One, } 7 \text { (2). } & \text { DOI: }\end{array}$ https://doi.org/10.1371/journal.pone.0032432.

Lavryshyn YY, Varkholyak IS, Martyschuk TV, Guta ZA, Ivankiv LB, Paladischuk OR, Murska SD, Gutyj BV and Gufriy DF. (2016). The biological significance of the antioxidant defense system of animalsanimals' body. Scientific Messenger LNUVMBT named after S.Z. Gzhytskyj, 18, 2(66): 100-111. DOI: https://doi.org/10.15421/nvlvet6622

Livanov GA (2008). Diagnosis and treatment of pulmonary hyperhydration in critically ill patients with acute poisoning with neurotropic substances. Anesthesiology and resuscitation, 6: 27-30. DOI or Available at: https://pubmed.ncbi.nlm.nih.gov/19227289

Matsuda K,Buckingham SD,Kleier D,Rauh JJ,Grauso Mand Sattelle DB (2001). Neonicotinoids: insecticides acting on insect nicotinic acetylcholine receptors. Trends Pharmacol Sci., 22 (11): 573-580. DOI: https://doi.org/10.1016/s0165-6147(00)01820-4.

Mohamed F et al.. (2009). Acute human self-poisoning with imidacloprid 
Dukhnytskyi et al., 2020

compound: a neonicotinoid insecticide. PLoS One, 4 (4): 5127. DOI: https://doi.org/10.1371/journal.pone.0005127.

Mossa H, Mohafrash M and Chandrasekaran N. (2018). Safety of Natural Insecticides: Toxic Effects on Experimental Animals. Hindawi. BioMed Research International, 2018: 4308054. DOI: https://doi.org/10.1155/2018/4308054.

See AM, McGill SE, Raisis AL and Swindells KL (2009). Toxicity in three dogs from accidental oral administration of a topical endectocide containing moxidectin and imidacloprid. Australian

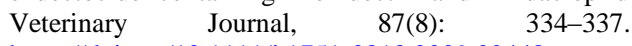
https://doi.org/10.1111/j.1751-0813.2009.00448.x.
Smith HA, Nagle CA, MacVean CA and McKenzie CL (2016). Susceptibility of Bemisia tabaci MEAM1 (Hemiptera: Aleyrodidae) to Imidacloprid, Thiamethoxam, Dinotefuran and Flupyradifurone in South Florida. Insects, 7 (4): 57. DOI: https://doi.org/10.3390/insects7040057

Tomlin C (20062009). The pesticide manual: a world compendium. Alton, Hampshire: BCPC. British Crop Protection Council. 14th edition. Surrey, P. 598-599. DOI or Available at: https://trove.nla.gov.au/work/6273016?q\&sort=holdings+desc\&_=1 $\underline{590006449179 \& \text { versionId }=46783185}$ 